\title{
NOTES
}

\section{ANOTHER EARLY REVIEW OF DEMOCRATIC VISTAS}

The critical response that greeted the appearance of Democratic Vistas has been described as "a conspiracy of silence." "Democracy" (lines 368-893 of the New York University Press text of Democratic Vistas) appeared in The Galaxy in December 1868 and is known to have received a couple of unfavorable notices; "Personalism" (lines 894-1275 of the cited text) appeared the following May and did even worse. The lengthy final section of the essay is apparently the same "Orbic Literature" article declined by The Galaxy, possibly because of its length, possibly because of what H. L. Mencken called "the gnarled and gasping style" of Democratic Vistas, or possibly because of the lack of critical or popular acclaim for the two published pieces. Nor did the completed Democratic Vistas, which included a 20-paragraph introduction and was issued as a 75-cent pamphlet, receive much recognition. Scott Giantvalley records a paragraph in the New York Times in 1870 and three items from English sources: the favorable discussion of the essay in Edward Dowden's discursive review of Whitman's writings in the Westminster Review in 1871, a passing friendly reference by Swinburne the following year in the Fortnightly Review, and a passing reference by Roden Noel in 1886 . No further notices are recorded prior to the appearance of the English edition of the essay in $1888 .^{2}$ To this small tally we may add one more favorable review - a review with which Whitman was acquainted.

On 21 August 1870, William Michael Rossetti, editor of Poems of Walt Whitman, sent a letter to Mrs. Anne Gilchrist containing the following lines:

I had a letter lately from a somewhat interesting man-Dixon of Sunderland-the "Corkcutter" to whom Ruskin's Time \& Tide is addressed. He says: "I got quite a treat lately. Whitman sent me his Democracy, \& the Radical, with a lady's opinion on his poems. They are quite the rage here among Whitman's readers that I know have them." ${ }^{3}$

The Dixon referred to is Thomas Dixon, one of a small, mystically inclined circle of Whitman's admirers in the English seaport town of Sunderland. The Boston Radical contained Mrs. Gilchrist's anonymous essay "A Woman's Estimate of Walt Whitman," and the "Democracy" item was the Galaxy article of that name, since Democratic Vistas had not yet appeared. Although I cannot attribute the following review to Dixon or to anyone else, it is somehow fitting that it should have originated in Sunderland where the faith in the "seer," as Whitman is called in the review, ran deep.

The review printed below exists as a clipping in the Charles E. Feinberg collection of Whitman manuscript materials in the Library of Congress, together with the fragmentary drafts of passages from Democratic Vistas. I cannot identify the source of the reprint (can one of our readers do so?); nor have I seen the original in the Sunderland Times. The review is not genuinely critical; three-fourths of it is a patchwork of quotations, often garbled, run together, paraphrased, or altered. (The few quotation marks in the article are misleading.) Of the fifteen quotations I have identified, ranging from a few words to three passages of one hundred words or more, seven are taken from the 20-paragraph introduction, five from the "Democracy" section, and 
three from the final section ("Orbic Literature"). ${ }^{4}$ None are from the "Personalism" section, with its revolutionary concept that the men and women of the American common people will ultimately constitute a political and moral vanguard of the new democratic order.

California State University, Long Beach

HAROLd ASPIZ 


\section{DEMOCRATIC VISTAS. \\ (From the "Sunderland Times" of May 21st, 1872).}

An original thinker on the other side of the Atlantic, the magnanimous Walt Whitman, has lately been looking through democratic vistas. Having mastered the lessons of the past as much as any man, and scanned the present with a remarkably keen eye, he has turned his mental telescope on the future and sees visions there that we trust will by and by be realised. He tells us that America, filling the present with greatest deeds and problems, cheerfully accepting the past, including feudalism, (as, indeed, the present is but the legitimate birth of the past, including feudalism), counts for her justification and success almost entirely in the future. Sole among nationalities, the United States have assumed the task to put in forms of lasting power and practicality, on areas of amplitude rivalling the operations of the physical cosmos, the moral and political speculations of ages, long, long deferred, the democratic republican principle, and the theory of development and perfection by voluntary standards and selfsuppliance. He does not gloss over the appalling dangers of universal suffrage in the States. It is, in fact, to admit and face these dangers he is writing. His eyes are open to the people's crudeness, vices, caprices; but in spite of these he is hopefully confident. Not the least doubtful is he on any prospects of the material success of the American Republic. Quoting Vice-President Colfax, he describes the progress of the Union, which, we should remember, is still in its infancy. From a territorial area of less than nine hundred thousand square miles, it has expanded over four millions and a half,-a space fifteen times larger than Great Britain and France combined, with a shore-line, including Alaska, equal to the entire circumference of the earth. In trade and commerce,-railway traffic,-manufacturing, mechanical, and mining industry,-agriculture, - population,-the figures are correspondingly vast, and increasing by something like geometrical progression. But Walt Whitman is not satisfied with this, nor with any earnest or promise of material wealth to his native country. He says Democracy can never prove itself behond cavil, "until it founds and luxuriantly grows its own forms of arts, poems, schools, theology, displacing all that exists, or that has been produced anywhere in the past, under opposite influences." This is what he thinks is wanted in order to give America real Unity, a Soul, a Conscience. So far the New World Democracy, however great a success in uplifting the masses out of their sloughs, in materialistic development, products, and a certain highly deceptive superficial popular intellectuality, is an almost complete failure, he confesses, in its social aspects, in any superb general personal character, and in really grand religious, moral, literary, and esthetic results. "In vain," say he, "do we march with unprecedented strides to empire so colossal, outvying the antique, beyond Alexander's, beyond the proudest sway of Rome. In vain do we annex Texas, California, Alaska, and reach north for Canada and south for Cuba. It is as if we were somehow being endowed with a vast and more and more thoroughly-appointed body, and then left with little or no soul." "Everywhere, in ship, street, church, theatre, bar-room, official chair, are pervading flippancy and vulgarity, low cunning infidelity-everywhere, the youth puny, impudent, foppish, prematurely ripe-everywhere an abnormal libidinousness, unhealthy forms, male, female, painted, padded, dyed, chignoned, muddy complexions, bad blood, the capacity for good motherhood deceasing or deceased, shallow notions of beauty, with a range of manners, or rather lack of manners (considering the advantages enjoyed), probably the meanest to be seen in 
the world." Yet underneath all this, which is shocking enough, the eye of the seer beholds, steadily pressing ahead and strengthening itself, even in the midst of immense tendencies towards aggregation, the image of completeness in separation, of individual personal dignity, of a single person, either male or female, characterised in the main, not from extrinsic acquirements or position, but in the pride of himself or herself alone, - the idea of that Something a man is, standing apart from all else, divine in his own right, and a woman in hers, "sole and untouchable by any claims of authority, or any rule derived from precedent, state-safety, the acts of legislatures, or even from what is called religion, modesty, or art." The purpose of democracy - supplanting old belief in the necessary absoluteness of established dynastic rulership, temporal, ecclesiastical, and scholastic, as furnishing the only security against chaos, crime and ignorance-is, through many transmigrations, and amid endless ridicules, arguments, and ostensible failures, to illustrate, at all hazards, the doctrine or theory that man, properly trained in sanest, highest freedom, may and must become a law, and a series of laws, unto himself, securing and providing for, not only his own personal control, but all his relations to other individuals and to the State; and that, while other theories, as in the past history of nations, have proved wise enough, and indispensable perhaps for their conditions, this, as matters now stand in our civilized world, is the only scheme worth working for, as warranting results like those of Nature's laws, reliable, when once established, to carry on themselves. Few probably are the minds, even in the United States, that fully comprehend as yet the aptness of that phrase, "the Government of the People, by the People, for the People," which Americans inherit from the lips of Abraham Lincoln, - a formula whose verbal shape is homely wit, but whose scope includes both the totality and all minutae of the lesson which the New World is now engaged in learning itself, and will eventually teach to the whole world. Higher than the highest arbitrary rule, it is to train communities through all their grades, beginning with individuals and ending there again, to rule themselves. The problem which America has to solve is the inauguration, growth, acceptance, and unmistakeable supremacy among individuals, cities, States, and the Nation, of Moral Conscience, whose analogy in the material universe is what holds together the world, and every object upon it, and carries its dynamics on forever sure and safe. Its lack, and the persistent shirking of it, in life, sociology, literature, politics, business, and even sermonizing in these times, or any times, still leaves the abysm, the mortal flaw and smutch, mocking civilization to-day, with all its unquestioned triumphs. But Walt Whitman hails with joy the oceanic, variegated, intense practical energy, the clamorous demand for facts, even the business materialisms of the current age. For he expects they will at last engender, nourish, and develope ideas of a nobler kind, commensurate with humanity. The mark of progress is the growing mastership of the general inferior self by the superior self, in the individual, the nation, the race. And this is what he thinks, and we concur with him in thinking, America is destined to do, is doing, and will accomplish.

\section{NOTES}

1 Gay Wilson Allen, The Solitary Singer: A Critical Biography of Walt Whitman (New York: Macmillan, 1955), pp. 426-427.

2 For the history of Democratic Vistas, see Democratic Vistas, in Prose Works 1892, ed. Floyd Stovall (New York: New York University Press, 1964), pp. 361-362; Edward F. Grier, "Walt 
Whitman, The Galaxy, and Democratic Vistas," American Literature, 23 (1951), 341-348; Harold W. Blodgett, "Demoratic Vistas-100 Years Later," in Geschichte und Gesellschaft in der americaner Literatur, ed. Karl Schubert and Ursula Müller-Richter (Heidelberg: Quelle \& Meyer, 1975), pp. 114-131; Scott Giantvalley, Walt Whitman, 1838-1939: A Reference Guide (Boston: G. K. Hall, 1981), pp. 24-26, 27, 30, 34, 76. Mencken's comment appears in "The National Letters," in The Vintage Mencken, ed. Alistair Cooke (New York: Vintage, 1958), p. 86.

3 Letters of William Michael Rossetti Concerning Whitman, Blake, and Shelley to Anne Gilchrist and her Son Herbert Gilchrist, ed. Clarence Gohdes and Paull Franklin (1934; rpt., New York: AMS Press, 1968), p. 63.

4 The reviewer seems to have taken quotations as he read $D V$ from beginning to end. The quoted passages in the review, in the same order that they are quoted from $D V$, may be found in the New York University Press edition on pages 362, 363, 363, 363, 365, 370, 372, 374, $374,374-375,378,380,415,418-419,421-422$.

\section{WHITMAN AND VAN GOGH: STARRY NIGHTS AND OTHER SIMILARITIES}

Van Gogh's admiration for Whitman has been noted by scholars of both the American poet and the Dutch painter. ${ }^{1}$ He expressed his admiration in a letter to his sister written in the Fall of 1888:

Have you read the American poems by Whitman? I am sure Theo [their brother] has them, and I strongly advise you to read them, because to begin with they are really fine, and the English speak of them a good deal. He sees in the future, and even in the present, a world of healthy, carnal love, strong and frank - of friendship - of work - under the great starlit vault of heaven a something which after all one can only call God-and eternity in its place above this world. At first it makes you smile, it is all so candid and pure; but it sets you thinking for the same reason. ${ }^{2}$

There are a number of interesting similarities between the poet and the painter. Rather similar personality types, both approached life with remarkable intensity which Mark Van Doren has termed, in Whitman's case, "erethistic," i.e., ". . . persons whose organs and tissues are chronically in a state of abnormal excitement, who tremble and quiver when the rest of us are merely conscious that we are being interested or pleased." 3 They each responded powerfully to other human beings; their comradeship could have been neither easy nor comfortable because of their intensity. The issue of their sexuality is still interesting to psychologists long after the artists' deaths - the Freudian tendency is to identify van Gogh as a latent homosexual. Neither was terribly concerned with the trappings of proper dress or behavior. Whitman's lusty democratic stance is paralleled by van Gogh's belief in the essential dignity and worth of the common man so evident in his paintings of work-worn peasants. In the realm of art, they admired and were inspired by some of the same writers-most notably, Emerson, Dickens and Carlyle. While neither was religious in an orthodox or sectarian sense, both knew the Bible intimately and it is echoed throughout their work. Both were acquainted with and emulated Eastern art and philosophy. Finally, they saw themselves as intermediaries between the outmoded art of the past and the shining new art of the future. 